Prace Polonistyczne, seria LXXV, 2020

ISSN 0079-4791; e-ISSN 2450-9353

https://doi.org/10.26485/PP/2020/75/4

Kasper Pfeifer (D)

\title{
POLISH FUTURISM AND ITS PROJECT OF EMANCIPATION ${ }^{1}$
}

\section{KEY WORDS}

Futurism; utopian studies; aesthetic and politics; Polish literature; revolutions; Jacques Rancière; Bruno Jasieński

Futurism in Poland emerged on the promise of "a great and radical reconstruction and reorganization of the Polish life", as Bruno Jasieński declared in 1921. He wished to make the revolutionary change one of the conditions of futurization, which would free modern man from the lethargy caused by the dogmatism and backwardness of tradition (Jasieński 2014: 9). ${ }^{2}$ The futuristic turn to the future was supposed to break historical continuity and, in a firm, quasi-accelerationist act, allow Polish society to enter "the ideal tomorrow" (Graf 2018: 63). The problem is that despite the radical nature of the project, it ended up as an unfulfilled prophecy at best (Gazda 1974: 69). As Helena Zaworska claims, Futurism sprouted in countries where "the great twentieth-century transformations created [...] a beautiful myth of the future rather than the actuality", which meant that "modern civilization in Poland at the time was by and large only a future prediction" (Zaworska 1963: 199-239). In other words, if the fetishes of the futuristic aesthetic regime - metropolises, machines, and blessings of technology - belonged to any reality, it was not the actual, everyday reality of the country that lies on both sides of the Vistula river, in the times of the flourishing

Kasper Pfeifer - mgr, Institute of Literary Studies, University of Silesia, plac Sejmu Śląskiego 1, 40-001 Katowice; e-mail: pfeifer.kacper@gmail.com; https://orcid.org/0000-0002-6600-3306.

1 This article was supported by grant no. 2018/29/N/HS2/00791 from the National Science Centre, for the research project entitled - Politics of Aesthetics. Bruno Jasienski and his Works.

2 I have modified the translation to make it correspond more closely to the original text. See also: Stern 1969: 14. 
of Futurism. It is enough to say that Poland of the 1920s was a politically unstable, agricultural country haunted by the spectres of hunger and hyperinflation, a country in which horse-drawn carriages were the dominant means of transportation, rather than automobiles or planes (see: Glensk 2015; Ciepielewski 1965; Rose 1922; Żarnowski 1973). In many ways, Poland was similar to Italy and Russia. It is thus telling that it was in those countries, which, according to Immanuel Wallerstein's world-systems theory, should be described as peripheral or semi-peripheral, that Futurism found its most fertile soil (Wallerstein 2004, also cf. Ram 2012: 314-340; Berghaus 2009: 2).

The futuristic act of burying tradition had more to do with moving towards the new than with destroying the past at all cost (Stern 1969: 58). Since the reformist or "positivist" predilections of the members of the Polish Futurist movement have already been researched, this article intends to examine its anti-obscurantism in opposition to the reproduction of "unmodernity" in both material and non-material spheres of culture (Gazda 1974: 67; Lee 1982: 52-53). This will concern not only the battle against the lack inscribed in the concept of passéisme, fought on theoretical fields, but also the abolition of this lack and preparing the ground for the development of modern industrial civilization and accompanying forms of social life. These goals were to be achieved through creating new categories to describe reality, reforming language, and replacing the old social hierarchy with a horizontal structure.

Due to significant differences in opinions between the members of the movement, it is difficult to discuss Polish Futurism as a homogeneous trend (Trzynadlowski 1977: 101). In order to avoid superficial judgments, I will primarily analyze the programme texts of the movement. These writings, though most often signed by Bruno Jasieński, expressed the views shared by the entire group. In fact, sometimes they were even results of collaborations (Jarosiński 1983: 66). I perceive Futurism as the artists' anticipation of what was to come. Therefore, I will examine the Polish strand of the movement as oriented towards a vision of the future that was far from being just a dream or a vague premonition, but was based on an imperative of modernization. It delineated a path leading away from the "panoptical nation" towards "futurization", as the Futurists themselves put it. Thus, I will interpret the iconoclastic acts of the Polish Futurists - their violent rejection of the past - as a vigorous endeavour undertaken to put an end to the existing structures of power and to what Jacques Rancière calls the representative regime of art (le regime represéntatif de l'art), or in other words, the established hierarchy of genres, styles, and modes of speaking, and to produce new ones in their place (Stern 1969: 58-59). As will be shown, their aim was first to put a halt to the current of history (through the symbolic act of making the past fade 
into oblivion), and then to accelerate the revolutionary change. The latter objective shows that the Futurists' aspirations can be traced back to the revolutionary tradition discussed by Walter Benjamin, who claimed:

[w] hat characterizes revolutionary classes at their moment of action is the awareness that they are about to make the continuum of history explode. The Great Revolution introduced a new calendar. The initial day of a calendar presents history in time-lapse mode [...]. In the July Revolution an incident occurred in which this consciousness came into its own. On the first evening of fighting, it so happened that the dials on clocktowers were being fired at simultaneously and independently from several locations in Paris. An eyewitness, who may have owed his insight to the rhyme, wrote as follows [...]: "Who would believe it! It is said that, incensed at the hour,/ Latter-day Joshuas, at the foot of every clocktower,/Were firing on clock faces to make the day stand still" (Benjamin 2006: 395).

With this in mind, the proper subject of my analysis is the potentiality (cf. Czapliński 1992: 57) and the scope of the Futurists' vision of the future which can be compared to the notion of an ideal city founded on the so-called raw root (in cruda radice), in other words a city that is shaped freely and irrespectively of any limitation inherited from the past. ${ }^{3}$ As Anatol Stern claimed in 1923, "Futurism is a period of demolition preceding the time of construction" (Stern 1923: 8), thus begging the questions: what was this construction as well as "the radical reconstruction and reorganization" proposed by Jasieński supposed to look like, what was meant by the concept of "new people" and what, according to the Polish Futurists, waited to be discovered beyond the "ghetto of logic" (Jasieński 2014: 13)?

As regards the radical nature of the movement, one should take seriously their postulate of making art social, i.e. of conceptualizing art as a configuration of collective experience, which can be examined with the use of Jacques Rancière's definition of politics, which he sees as actions aimed at suspending the police paradigm of the distribution of the sensible (le partage du sensible), at intervening into the ways in which social roles and rules of conduct are organized, and thus predetermining all that is common (Rancière 2009b: 27). Having adopted such an approach, we should assign equal importance both to the radical postulates of the Futurists and their aesthetic and linguistic choices. Their focus on these

3 As a privileged locus of modernity, architecture and urban planning were an important aspect of futuristic reflection - the concept of La Città Nuova of Antonio Sant'Elia is particularly worth mentioning in this context. Although Polish Futurism did not produce any mature urbanistic concept, the theory of Sant'Elia (most likely mediated by Le Corbusier's writings) was well-known in Poland and was creatively recycled by Szymon Syrkus and the Praesens group. See: Syrkus 1926; Rybicka 2000: 60. 
issues is best visible in their interest in language, understood as the backbone of subjectivity. This was best expressed by Bruno Jasieński in his Manifesto of Futuristic Poetry (Mańifest w sprawie poezji futurystycznej, 1921):

[w]e write off logic as a bourgeois form of mind. Every artist has the right and the obligation to create his own auto-logic. [...] Poetry means composing words in such a way that extracts a word's maximum resonance, without exterminating its other, concrete soul. [...] We write off a sentence as an anti-poetic freak. A sentence is an accidental composition, stuck together only with the weak glue of philistine logic. Instead of a sentence - condense, sharp, and consistent compositions, unrestrained neither by syntax, nor by logic or grammar [...]. Constantly working and struggling to forge a tomorrow we wish to remain honest and aware (Jasieński 1978c: 19-20). ${ }^{4}$

Furthermore, in his Polish Futurism (a summary) (Futuryzm polski (bilans), 1923) Jasieński states:

[t]he consciousness of society resides in its art, understood as organized life. Each new phase of life requires new forms of art. It is only through creating these forms that a consciousness of a given time can be brought forth [...]. For a modern man, infected by the machine, art based on nonsense can be like a breath of artificial air, which allows him to momentarily break free from the ghetto of logic and construction and to find serenity in a moment's grace (Jasieński 1978a: 50, 62).

Futuristic interventions in language went far beyond merely proclaiming the experiment as the preferred form of artistic practice (Lipatow 1992: 55). It was not just about destroying syntax, questioning spelling rules, or simply playing with writing conventions. According to the Futurists, existing logical structures were predetermined by the dominant class (cf. Stern, Wat 1978: 4) which wishes to preserve the invulnerability of the grammar that underlies the so-called "common speech". As the sociologist Tony Bennett states,

[t]he bourgeoisie, by virtue of the facility acquired from an understanding of its mechanisms, experiences that language as its own. It is at home with it, familiar with its workings. The subordinate classes, by contrast, receive that language in an administered form, handed down from above within the education system. Familiar only with its shell, they experience the language as an exclusion and a limitation in relation to the "superior" literary language from which they are, by virtue of their class, formally excluded (Bennet 2003: 131). ${ }^{5}$

4 The translation does not convey the non-standard spelling of the original text. See also: Stern, Wat 1978: 5-6.

5 The source of this understanding of language by the Futurists can be found in the philosophy of Frederic Nietzsche (see Nietzsche 1989: 246-257). 
Accordingly, the futuristic questioning of the alleged "transparency" of language and the consequent destabilization of linguistic rules should be seen as a subversive attempt to violate and redistribute the Rancièrian police order of the sensible. "Anyone can be an artist", announced Jasieński, thus contesting the social elitism of artistic professions and advocating disregard for this elitism and the opaque language that reinforces it (Jarosiński 1983: 66). For the Futurists, liberating language from the narrow structures of official logic took the form of radical egalitarianism that necessitated overthrowing what Rancière calls the representative regime of art and promoting universal access to the possibility of a collaborative reconsideration of the predominant discursive practices and creation of a space in which new subjectivities may develop (cf. Rancière 2015: 373). As Sascha Bru argues, Antonio Gramsci analyzed futurist experiments with language to refine his theory of hegemony and to claim that every social struggle aimed at liberation gives rise to a new, anti-hegemonic language (Bru 2005: 119-132). The revolutionary potential that resides in exploding the structure of language was also noticed by the political adversaries of Futurism.

Those are no innocent jokes [...]. Will a mind fed with such literature not easily succumb to anarchist theories? Isn't all of this calculated to prepare the ground for the seeds of Bolshevism? Aren't these "poets" apostles designated by Trotsky's emissaries? (Wierzbiński 1921: 3).

Such concerns were articulated in the daily Polish newspaper "Rzeczpospolita" by Maciej Wierzbiński, a conservative writer and supporter of National Democracy. ${ }^{6}$

Having in mind the Futurists' awareness of the dependence of the social hierarchy on language, let us consider the Aristotelian definition of a political being, which Jacques Rancière often mentions in his writings (Rancière 1998: 2). According to the first book of Politics, a human (political) animal uses speech, or logos, while a non-human animal is speechless and all it has is phônê, a voice which, though fit for expressing joy or pain, cannot be used to discuss usefulness or righteousness. ${ }^{7}$ Thus, a distinction is made between the subject and the object of political life. According to Aristotle, the latter consisted of excluded or dominated groups, such as slaves, women, and craftsmen - those whose voice is socially inaudible. To explain the problem in Rancièrian terms, I argue that, by rejecting the bourgeois logos and attempting to replace it with the intensity of a scream, instead of fighting for the recognition of the latter as an equivalent

${ }^{6}$ National Democracy (Narodowa Demokracja) was a far-right nationalist party that was active in Poland from the second half of the nineteenth century to 1939.

7 According to Anatol Stern, the Futurists' attacks against tradition were, among other things, targeted at the logos which symbolized a conservative attitude towards hierarchy and culture (Stern 1969: 61). 
of speech, the Futurists tried to create a horizontal form of subjectivity founded upon privileging human phônê, the voice through which underprivileged people express themselves as equals. Such an attitude towards language was conspicuous in both theoretical reflection and artistic practice of the Polish movement and especially in the primitivist poetry of Anatol Stern and in a somewhat discursive form of the works of Bruno Jasieński. In the famous poem entitled I Got Tired of Language (Zmęczyt mnie język) Jasieński wrote:

Let go or I will scream like a boor!

And I punch the rigid windowsill.

In my apartment I have much better

wallpapers of poems and poems of wallpapers!

Poetry! Paramour of elegant sirs!

Anaemic, timid, pale masturbators!

Away with you! Today I praise dark, vulgar boors

who couldn't tell France from a prance.

[...]

I will create a new art, an art for black cities.

It will be strong, like vodka, and as good as gingerbread.

You'll be surprised by all the stars in the sky

never before discovered by any Copernicus.

(Jasieński 2008: 214-216)

It seems that poetry - the "paramour of elegant sirs" - is to be replaced by a completely new democratic creation (Krzychylkiewicz 2006: 82), a new language, an unsophisticated roar that will cause the collapse of the existing Rancièrian police regime of representation. In other words it will challenge the existing social hierarchy and the means of its legitimization and venture beyond the horizon outlined by traditional power-knowledge complex (cf. Rancière 1998: 1-5). Although the legacy of Polish Futurism is not rich in properly developed words-in-freedom (parole in libertà), i.e. words that would break down the imperative logic of language, the theory developed by the members of the movement left its mark on the more specific, revolutionary postulates expressed in the programmes of Polish Futurism. It also influenced the Futurists' belief that art, by destabilizing the dynamics of the existing aesthetic regime, can set the stage for a revolution (Graf 2018: 428-445; Jarosiński 1978: CII-CVI). After all, taking control over the means of artistic production was the starting point for pursuing the futurist goal of reconstructing social life. As Jasieński put it, "[in order to bring about a revolutionary change,] Polish society has to control and supervise social life and production of all types [...]. The first essential step is to control all artistic production" (Jasieński 2014: 15). 
Hence the Futurists' conclusion that the place of art is in the streets and that what is both novel and common constitutes the avant-garde (Lee 1982: 57). They wished to "socialize" art in a way which would turn it into a mass phenomenon or simply make it more available thanks to "travelling poetry-concerts, concerts in trains, trams, canteens, factories, cafés", etc. (Jasieński 2014: 13). The whole multitude of people was to cooperate in a collective act of co-creation. As Jasieński put it, "[w]e don't need any intermediaries for our art. We can be its creators, its promoters, and its followers at the same time" (Jasieński 1978b: 24). Works of art were to be removed from their pedestals and temples (operas, theatres, galleries, and palaces). They were to help construct a new social reality in which widely available art would be co-experienced by the masses. This idea stood in stark contrast to the system of art production maintained by the upper class that commissioned artworks from an elite group of artists who remained secluded in their studios. The Futurists' unfulfilled plan to abolish the so-called institution of "Art", as Peter Bürger put it (Bürger 1984: 83), was to result in the annulment of the hierarchy of artistic expression, the abolishment of the police distribution of the sensible which drew clear boundaries between the vulgar/the folk and what should be considered real art (Rancière 2009a: 1-19). Perhaps this is where the fascination of Polish Futurists with folklore (Młodożeniec, Czyżewski, Jasieński in The Tale of Jakub Szela) and the primitive (Stern) stems from (cf. Stępień 1985; Burkot 1985; Rawiński 1971).

The theories of a-logical language, experimentation, and massification of art paved the way for recognizing the value of the common class and the mob whose significance was investigated in a nuanced way in the artistic practice of Polish Futurists (Wójtowicz 2019: 31). While conservatives saw the empowerment of the masses as a harbinger of the destabilization of the social apparatus founded upon the power derived from birth and wealth, the Futurists perceived the empowerment of the common people as a force that could uproot a system created by - to quote from Anatol Stern's and Aleksander Wat's manifesto from 1920 - "stupid idiots and capitalists" (Stern, Wat 1978: 3). Published a year later, A Manifesto to the Polish Nation on the Immediate Futurization of Life (Do narodu polskiego. Mañifest w sprawie natyhmiastowej futuryzacji żyća) - a result of a collaboration of the futurist circles from Warsaw and Cracow written down by Jasieński - developed these ideas in a radical manner (Lee 1982: 64):

[t]ime to clear the pedestals, sweep out the squares, prepare places for those who are coming. [...] We are beginning to build a new home for an extended Polish Nation that has outgrown the old one [...]. The great shifting of [the social] strata in the East and the West continues. A new force is speaking out - the conscious proletariat. All values are being reevaluated. They are pitting themselves against the whole 1000-year- 
-old legitimacy and illegitimacy of the culture produced on their backs and at their expense. [...] We appeal to the "new people", untainted by this syphilitic civilization, whom the worldwide war flushed from the surface and whom the old civilization continues to treat like bastard children. We, the futurists, are the first to reach out in fraternity to the "new people". They will be a fortifying, invigorating juice to rejuvenate the old, deteriorating race of yesterday's people, a painful but necessary vaccine that the great historical cataclysm has injected into a moldering prewar Europe, whose stench was beginning to rankle the nose (Jasieński 2014: 10-11, 16).

The manifesto elaborated on what Stern and Wat summarized in just a few words. The Futurists saw the new proletariat rising on the horizon as a self-conscious, progressive class. Unlike the "yesterday's people" looking down on the commoners from the high horse of their sophistication, the Futurist's proletariat is not burdened with centuries of tradition and the bourgeois habits that led Europe to moral decay and, as a result, to the "historical cataclysm" of the Great War. The main role of the proletariat on the stage of history was to help the lower classes settle an old score and finally pass a judgement - most probably a condemning one - upon the culture that was entirely founded on the exploitation of one class by another. The paragraph that has been quoted above deserves attention not only because it repeats the revolutionary call to arms of the ussian Futurism, but also because this call was adapted to the situation of the interwar Poland. In this context, the promise of erecting a "new home for an extended Polish Nation" comes to the fore. Taking into account the fact that the Polish Futurists did not hide their interest in the common class and its history, it may be assumed that they wished to extend the idea of a nation, the semantic field of which did not include such social groups as the peasantry or the urban mob, since the term was created by the Polish gentry (Rauszer 2018; Łuczewski 2012). When studying the culture of the interwar period, one cannot forget that in the years following the Treaty of Versailles, a wave of protests, strikes, and riots organized by rural workers and the proletariat swept through Poland. Even though these actions were dispersed and seemingly unrelated, what united them was the demand for social change. ${ }^{8}$ This unrest took a special form in rural areas, where the positive programme was sometimes mixed with a resentment fuelled by the memory of serfdom. As Wincenty Witos, who was at the time the leader of the Polish peasant movement, wrote in his memoirs, "the peasants were extremely terrified of [independent state of] Poland, because they believed that

8 One should mention the unrest in the rural areas surrounding the city of Lublin at the turn of 1919, the railwaymen strike in Poznań in 1920, or the famine riots in Rawicz (1921). The so-called Cracow Uprising, which took place in 1923, was the most well-known instance of the working class insurrection. All of these rebellions were violently suppressed by the authorities. 
when it returns, serfdom and the horrible slavery ordained by the nobles will come back, too" (Witos 1988: 102).

Witos was not the only one to make such claims. Years later, the famous poet Czesław Miłosz expressed a similar understanding of social relations in Poland, which he saw as an "extension" of feudalism (Miłosz 1999: 267). Undoubtedly, even though feudal modes of exploitation were abolished in Poland in the mid-nineteenth century, its "spectres" that haunted Polish collective memory were not properly exorcized. It may be argued that the will to broaden the semantic range of a "nation" so as to make it more inclusive towards those that were previously excluded not only points towards the egalitarian foundations of Futurism, but also suggests that the members of the Polish movement recognized the need to reinforce the new symbolic order by rejecting the idea of a society based on exclusion. This is further visible in the rejection of the accessories that were commonly associated with the upper class: "let us shed the umbrellas, hats, bowlers, we will walk with our heads uncovered. Bare necks. Everyone must get as dark a tan as possible" (Jasieński 2014: 12). A tanned, dark complexion did not fit the nobles' canon of beauty in Poland and was widely regarded as a distinctive feature of commoners. Back in 1894, in a book entitled Charakterystyka antropologiczna szlachty drobnej (Anthropological Characteristics of Petty Gentry), Władysław Olechnowicz tried to prove that alabaster skin is characteristic of nobility, as opposed to the more swarthy complexion of the lower classes. ${ }^{?}$

What is more, the egalitarianism of the Polish Futurists, who recognized and contested the division between the subject of political life and the object of power, went beyond the context of class and social affiliation and reached for gender hierarchies. As Jasieński put it,

[a]mong the architectural, visual, and technological works of art we can distinguish one - THE WOMAN - as the perfect reproductive machine. Woman is an untapped and incalculable force, remarkable in her influence. We demand absolute equality for women in all spheres of life, both private and public. Above all - equality in erotic and family relationships. The number of married couples who live apart or are officially separated has soared to such heights as to undermine the fabric of society. We deem the immediate introduction of divorce to be the only way and halt this process (Jasieński 2014: 14-15).

9 This is connected with the ethno-genetic myth of Polish nobility. Peasant genealogy was traced back to the dark-skinned Ham, the biblical son of Noah. According to the Judeo-Christian tradition, his descendants were cursed and condemned to slavery by the patriarch, thus becoming the ancestors of the more contemporary people of North Africa. The genealogy of the nobles was, by contrast, traced to the descendants of Noah's second son - the fair-haired and fairskinned Japheth, whom the descendants of Ham were supposed to serve. Cf. Kuligowski 2016: 72; Pobłocki 2016: 107-119; Kidd 1999: 29. 
The basic difficulty in analyzing the Polish Futurists's attitude towards gender equality resides in the formulations indicating a kinship between women and machines. On the one hand, these comparisons may be seen as placing the woman in a privileged position. By equating her with a product of technology, the Futurists put her on par with the objects of their fundamental fascination and treated as the very source of their reflections on the issues related to modernity. Phallogocentrism reserves the technological sphere for men, juxtaposing their alleged affinity with culture and technology with the alleged connection between women and sensuality and nature (cf. Butler 1999: 48). Nonetheless, the above-mentioned postulates may as well be read as rooted in the traditional, patriarchal discourse which shows the man as a chivalrous defender and a righteous father. ${ }^{10}$ Remembering that "Polish national culture is to a great extent a male culture", it may be argued that the contextual analysis of the emancipatory message of Polish Futurism helps explain this ambivalence and show the true potential of the Futurist's ideas (Janion 2017: 267). Along with the demand for equal rights for women in social and political life (see: Łysko 2015) came the necessity to equate women with men in erotic relations and to legalize divorce in Poland. ${ }^{11}$ This led to the at least partial questioning of the system of production dependent on unpaid female labour: reproduction, care-giving, and all the affective labour performed in marriage (Foucault 1999: 115-130; Theweleit 1987: 310-314). The futurist demands regarding sexual relationships were, thus, aimed at the system of rituals and prohibitions imposed on female sexuality by the patriarchy. These demands can, therefore, be seen as consistent with the views of Polish feminists - such as, for example, Irena Krzywicka, who argued that bringing equality into the sexual sphere is one of the factors that will help women to free themselves from male domination and develop a strong subjectivity (Krzywicka 2008).

We should also discuss the controversial comparison of women to works of art. Although it brings to mind the modernist aestheticization and objectification of femininity, which evidently differs from models of radical emancipation due to, among other things, the fact that it frequently employs objectifying practices, one should remember that the Futurists believed that an artwork can provoke historical change. Thus, emphasizing the need to emancipate women and desta-

${ }_{10}$ To learn more about the problems that the Polish Futurists encountered when they tried to challenge tradition, see: Graf 2018: 63-82.

${ }^{11}$ In interwar Poland, there were no general laws that would apply to the whole country. Instead of falling within state jurisdiction, divorce remained within the jurisdiction of ecclesiastical courts and was regulated by canonical law (which, in most cases, did not allow for a divorce). The annulment of marriage by a civil court was only available in the former Prussian partition of Poland. This resulted in the growing popularity of the so-called "divorce tourism". Cf. Fastyn 2014: 133-151. 
bilize the traditional system of distribution of social roles can be regarded as the spiritus movens of futurization, a factor stimulating the potential emergence of a horizontally structured society. It is worth noting that the ideas put forward by the Futurists were in some respects close to many feminist postulates of the times under discussion, especially when it comes to the perception of the concept of romantic love as a site of power and the repression of female sexuality (Millet 1990: 33-37). This became visible, inter alia, in the futuristic criticism of "sexual tragedies à la Przybyszewski" (Jasieński 2014: 15) ${ }^{12}$ and in urging women to take the initiative, which was tantamount to advocating the separation of sexual needs from emotional or marital motivations and, at least to some extent, liberating the female body from the territory of male domination and, at the same time, sanctioning the autonomy of female desire (cf. Millet 1990: 37). As far as the attitude of the Futurists towards the problem of women's emancipation is concerned, one should not forget that the masses fetishized by the movement were strongly feminized. As Klaus Theweleit states, the crowd and its illogical, natural savagery are to the world of culture what, in the patriarchal world, a woman is to a man (Theweleit 1989: 45). It could be, therefore, argued that since the Futurists opposed the individualism of philistine men, then they also opposed giving masculinity the status of the one and only culture-forming force (Theweleit 1989: 541-543). The restless multiplicity favoured by the Polish Futurists was thus a heterogeneous mixture co-constituted by both women and men. In spite of all this, one should emphasize that the set of demands for women's equality that was voiced by the Polish Futurists to a large extent followed the patriarchal logic and that the movement's attempt at breaking free from this logic led to only a partial success. They unconsciously retained the "old models" and filled them with supposedly new content, as Alexandra Kollontai puts it in her analysis of the anti-patriarchal aspects of the Russian Revolution (Kollontai 1977).

In order to carry out their somewhat aporetic project and create a hierarchyfree society, the Futurists planned to create a nationwide group, an inclusive party of "people rushing towards tomorrow" (Jasieński 2014: 16) that would help them achieve the futuristic goal. Anyone, regardless of their gender, nationality, or class affiliation, could become a member. It was enough for such a person to "instinctively sense the moment of cultural crisis and to want to find a way out" (Jasieński 2014: 16) in a futurist manner, or simply to be looking for a way out of the stratified world of the rulers and the ruled. The enthusiastic Futurists announced that " $[\mathrm{e}]$ veryone can henceforth become the creator of his own life

12 Stanisław Przybyszewski (1868-1927) - a Polish modernist writer and poet who was famous for his promiscuity and misogyny. 
and life in general" (Jasieński 2014: 16) and explained the organization of their party in the following way:

[e]veryone and no one can be a leader. Total decentralization. We know neither leaders nor foot soldiers, everyone is a full-fledged employee of a valiant life [...] (we don't need to name them - only common and universal people exist) (Jasieński 2014: 16). ${ }^{13}$

This step towards making the movement common was supposed to solidify the people into a political entity capable of creating an ideal world which had until then remained only potential, rather than actual. Furthermore, the futuristic idea of entering modernity thanks to freedom from the hierarchical apparatus of power was by no means ahistorical. To the contrary, the members of the Polish movement saw their opportunity in how the cataclysm of the Great War weakened the rigid structures of bourgeois morality which, despite all the signs of the crisis, remained fused with dominant discourses prior to 1914 (Hobsbawm 2015: 297-308). It is not without reason, then, that the Polish futurists spoke of futurization in terms of a potentiality that could disrupt the hitherto unchallenged order, allowing for "the perspective of the new possibility", to use Alain Badiou's turn of the phrase (Badiou, Tarby 2013: 14). Whether it would catalyze change or be remembered as merely another missed chance was to be determined based on the effectiveness of the effort to produce new canonical forms of knowledge:

Polish life has entered a whole new phase, waking to a million issues at its doorstep, which there had never been time even to contemplate, but which now require a swift and categorical response. Lest another wave come crashing down on us [...] if we cannot devise new categories to fit the new art [...] we will not survive [...]. If you don't want to be dead last in Europe - if, on the contrary, you want to be first - stop eating the West's kitchen scraps (we can afford our own menu) (Jasieński 2014: 11). ${ }^{14}$

Jasieński returned to this problem in his well-known text summarizing the achievement of Polish Futurism:

When in 1918, after returning to Poland, I got in touch with Titus Czyżewski for the first time - we saw one thing: lush contemporary life broke the dams of the trenches and barbed wires and flooded the sea of Polish psyche with incredible power [...]. A society that does not create new forms of organization in proper time will be [...] overcome, defeated, saddled by the moment of modern life, which it is not able to manage. [...] The introduction of the machine into human life as its indispensable, complementary element had to involve rebuilding human psyche thoroughly [...].

\footnotetext{
13 Cf. Miller 1925: 47.

${ }^{14}$ See also: Czyżewski 1978: 40.
} 
A vast number of new objects of civilization emerged before the thoroughly romantic Polish psyche, in the production of which it didn't actively participate. [...] It was necessary to immediately [...] create forms that would help [the Polish psyche] reclaim the heritage of machine civilization not as a dead burden, but as its own internal creation, or create forms that would subordinate the machine to the Polish psyche (Jasieński 1978a: 50-51, 60).

In other words, if modernity, technology and "new forms of organization" were to bring forth equality, their dissemination in social life would have to be preceded by the development of categories and concepts that could describe the new reality in such a way that would, first, make it possible for people to call it home and, second, transform the potential universality of the machine into a driving force of empowerment, rather than another force strengthening the apparatus of power and immunizing the art regime against grassroots interventions in the distribution of the sensible. A new language, a new way of naming and speaking about the past, the present and the future, and the abandonment of outdated categories and descriptions of the world were to be the basis of politics, defined in Rancièrian terms as "the process of undermining existing distributions, disrupting the structure by supplementing it with an additional element: participation in the community granted to those who were excluded from it" (Franczak 2012: 188).

The forward-looking project of the Polish movement focused on the implementation of the proposed transformations within the Polish borders which were established in the early 1920s. To use Benedict Anderson's term, the Futurists' postulates were addressed to an imagined community - an "extended Polish nation". Regardless of how the Futurists specified their purposes at a given moment, their main aim was to achieve a "radical reconstruction" or a quasi-accelerationist futurization (Jaworski 2018: 76). It seems to be quite intriguing that this was an attempt to antagonize Poland with the West, to challenge the power constellation that gives hegemony to the core and ties the periphery with the notion of "unmodernity" (Ram 2012: 314). Within the Polish Futurist movement, one may find those who objected to such an understanding of modernization (that is deeply rooted in the Polish intellectual tradition, cf. Janion 2017: 223-235) - an understanding that supported the symbolic privilege of the core countries and identified progress not so much with actually keeping up with time and novelties, but with a superficially conceived "de-Orientalization" of a given peripheral country, to use Said's turn of the phrase, and its inclusion in the prestigious ranks of the modern "West" (Said 1979). This objection is even more interesting if one views it in the context of the intensification of the exclusionary discourse in the times of the Polish-Soviet war (1919-1921) when 
Poland (seen as modern and closely associated with the West) was contrasted with the barbarism lurking in Asian Russia (Pogonowska 2002: 93-132). The main goal of the modernizing projects of the Polish Futurists was, therefore, not to beg for Poland to be included - granted the status of a core state by the other core nations - but to undermine the logic drawing the line between the core and its periphery, to do away with the division into dominant and dependent countries, and, in consequence, to put an end to "eating the West's kitchen scraps". As Harsha Ram points out, this rebellious attitude towards the very logic of the core and the periphery was one of the features that were common to various types of Futurism worldwide. It found a reflection even in the above-mentioned projects which were designed, firstly, to destroy the existing hierarchy of the literary genres and styles and its language, secondly, to undermine the hierarchy and exclusion that characterize capitalist methods of production, and, thirdly, to deal a symbolic, yet deadly blow to the core, as Bruno Jasieński did in his famous novel, I Burn Paris.

The entire array of postulates and proposals of radical transformations of the social fabric of interwar Poland leaves no room for doubt that Polish Futurists set their goal far beyond the mere provocation of the bourgeois audience. Although it is difficult to ignore the apparent discrepancies between the views of individual members of the movement, as well as both contradictions and understatements present in the postulates made in their manifestos, one nonetheless has to take into account the Futurists' high sensitivity to social issues. In so doing, I wish to highlight the positive aspects of the futurist utopia. According to Zygmunt Bauman, a utopia, which, as a term, is highly susceptible to devaluation, "marks the end, not the beginning of an argument" (Bauman 1976: 9). In fact, a utopia points to an alternative, exposes the shortcomings of the present reality, allows one to consider completely new possibilities, and find new horizons. In other words, a utopia transforms a dream of social change into a potentiality. As Bauman argues,

it is rather the boldness of the utopian insight into the unexplored future, its ability to cut loose and be impractical, which sets the stage for a genuinely realistic politics, one which takes stock of all opportunities contained in the present (Bauman 1976: 13).

I believe this was the reason why the famous researcher of the Polish avant-garde, Helena Zaworska, declared the futurist idea of a "new people" one of the greatest achievements of the movement (Zaworska 1963: 204). Having in mind the fact that the futurist endeavours were fuelled by the pursuit of universal equality, such a statement can hardly leave one indifferent. The failure of the movement's forward-looking project left the Futurists embittered for years, their 
defeat haunting them for a long time after the decline of the heroic period of Polish Futurism. In 1929, in a poem called Europe, Anatol Stern thus expressed the ruin of his dreams:

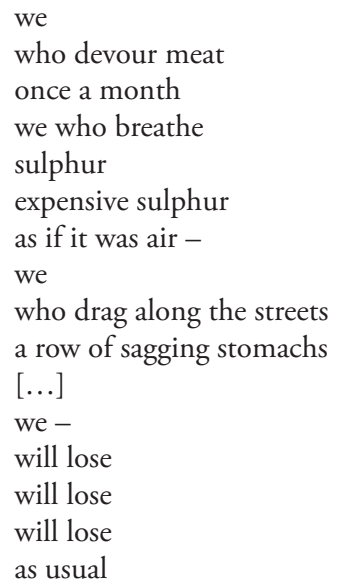

(Stern 1985: 200)

To conclude, Futurism's utopian opposition to passéisme and tradition, and its predilection for the future should be interpreted as a form of disagreement with "the absence of modernity", and, simultaneously, as a positive project whose ultimate goal was to blaze a trail to an ideal and egalitarian future right through the existing forms of social life, the language that propelled the machinery of the power-knowledge complex, and the governing practices used in a hierarchical society. The Futurists implored society to abandon the past and destroy it, for what was at stake was a chance to establish a new, unprecedented order. The brave new world that would thus be born was to come into existence thanks to futurization - the acceleration of the course of history. Hence, the vision of the Futurists could not come true thanks to persistent reformism - it could only be a result of a revolution, a radical introduction of equality and social progress.

The essence of the change of which the Futurists dreamed was to suspend the current order and to outline a potential vision - a combination in a way reminiscent of one of Walter Benjamin's well-known concepts. His angel of history, even when he is advancing, his gaze is turned backwards, to the past. The futuristic quasi-accelerationism is an inverted angel of history - the angel moves forward and focuses his eyes only on the future. 


\section{BIBLIOGRAPHY}

Badiou Alain, Tarby Fabien. 2013. Philosophy and the Event. Trans. Louise Burchill. Cambridge-Malden: Polity. ISBN: 978-07-4565-395-2.

Bauman Zygmunt. 1976. Socialism. The Active Utopia. London: Allen and Unwin. ISBN: 978-00-4300-050-5.

Benjamin Walter. 2006. On the Concept of History. In: Selected Writings. Volume IV: 1938-1940. Ed. Howard Eiland, Michael W. Jennings. London: Belknap. ISBN: 978-06-7402-229-4. Pp. 389-400.

Bennett Tony. 2003. Formalism and Marxism. London-New York: Routledge. ISBN: 978-04-1532-151-8.

Berghaus Günter. 2009. Futurism and the Technological Imagination Poised between Machine Cult and Machine Angst. In: Futurism and the Technological Imagination. Ed. Gunter Berghaus. Amsterdam-New York: Rodopi. ISBN: 978-90-4202-747-3. Pp. 1-40.

Bru Sascha. 2005. Morbid Symptoms: Gramsci and the Political Rhetoric of Futurism. "Journal of Applied Statistics", no. 13. ISSN: 0266-4763. Pp. 119-132.

Burkot Stanisław. 1985. Stanistaw Mtodożeniec. Rzecz o chtopskim futuryście. Warszawa: Ludowa Spółdzielnia Wydawnicza. ISBN: 978-83-2053-660-7.

Butler Judith. 1999. Gender Trouble. Feminism and the Subversion of Identity. New YorkLondon: Routledge. ISBN: 0-203-90279-3.

Bürger Peter. 1984. Theory of the Avant-Garde. Trans. Michael Shaw. Minneapolis: University of Minnesota Press. ISBN: 978-08-1661-068-6.

Ciepielewski Jerzy. 1965. Wieś polska w latach wielkiego kryzysu 1929-1935. Materiaty i dokumenty. Warszawa: Książka i Wiedza.

Czapliński Przemysław. 1992. Manifest literacki jako jednostka procesu historycznoliterackiego. "Teksty Drugie", no. 1/2. ISSN: 0867-0633. Pp. 57-72.

Czyżewski Tytus. 1978. Pogrzeb romantyzmu - uwiąd starczy symbolizmu - śmierć programizmu. In: Antologia polskiego futuryzmu i Nowej Sztuki. Ed. Zbigniew Jarosiński, Helena Zaworska. Wrocław: Ossolineum. Pp. 39-41.

Fastyn Arkadiusz. 2014. Przeszkoda katolicyzmu (impedimentum catholicismi) w prawie województw potudniowych II Rzeczypospolitej. "Czasopismo Prawno-Historyczne”, no. 2. ISSN: 0070-2471. Pp. 133-151.

Foucault Michel. 1999. Sexuality and Power (1978). In: Religion and Culture. Ed. Jeremy R. Carette. New York: Routledge. ISBN: 978-04-1592-362-0. Pp. 115-130.

Franczak Jerzy. 2012. Jacques Rancière: historia literatury i polityka. "Teksty Drugie”, no. 3. ISSN: 0867-0633. Pp. 187-196.

Gazda Grzegorz. 1974. Futuryzm w Polsce. Wrocław: Ossolineum. 
Glensk Urszula. 2015. Historia stabych. Reportaż $i$ życie $w$ dwudziestoleciu. Kraków: Universitas. ISBN: 978-83-2422-643-6.

Graf Paweł. 2018. Automobil w pędzie. Studia o futuryzmie i futurystach. Poznań: Wydawnictwo Naukowe UAM. ISBN: 978-83-2323-363-3.

Hobsbawm Eric. 2015. Wiek imperium 1875-1914. Trans. Marcin Starnawski. Warszawa: Wydawnictwo Krytyki Politycznej. ISBN: 978-83-6536-903-1.

Janion Maria. 2017. Niesamowita Stowiańszczyzna. Fantazmaty literatury. Kraków: Wydawnictwo Literackie. ISBN: 978-83-0806-196-1.

Jarosiński Zbigniew. 1978. Wstęp. In: Antologia polskiego futuryzmu i Nowej Sztuki. Ed. Zbigniew Jarosiński, Helena Zaworska. Wrocław: Ossolineum. Pp. III-CXXIII.

Jarosiński Zbigniew. 1983. Literatura i nowe spoteczeństwo. Idee lewicy literackiej dwudziestolecia międzywojennego. Warszawa: Czytelnik. ISBN: 978-83-0700-816-5.

Jasieński Bruno. 1978a. Futuryzm polski (bilans). In: Antologia polskiego futuryzmu i Nowej Sztuki. Ed. Zbigniew Jarosiński, Helena Zaworska. Wrocław: Ossolineum. Pp. 49-63.

Jasieński Bruno. 1978b. Manifest w sprawie krytyki artystycznej. In: Antologia polskiego futuryzmu i Nowej Sztuki. Ed. Zbigniew Jarosiński, Helena Zaworska. Wrocław: Ossolineum. Pp. 23-24.

Jasieński Bruno. 1978c. Mańifest w sprawie poezji futurystycznej. In: Antologia polskiego futuryzmu i Nowej Sztuki. Ed. Zbigniew Jarosiński, Helena Zaworska. Wrocław: Ossolineum. Pp. 17-22.

Jasieński Bruno. 2008. [Zmęczyt mnie język] Bruno Jasienski: "But w butonierce". In: Poezje zebrane. Ed. Beata Lentas. Gdańsk: słowo/obraz terytoria. ISBN: 978-837453-708-7. Pp. 214-221.

Jasieński Bruno. 2014. To the Polish Nation: A Manifesto on the Immediate Futurization of Life. In: The Legs of Izolda Morgan. Selected Writings. Trans. Soren Gauger, Guy Torr. Prague: Twisted Spoon. ISBN: 978-80-8626-440-0. Pp. 9-17.

Jaworski Krzysztof. 2018. Znani-nieznani, ale zawsze ciekawi. O listach Brunona Jasieńskiego do Stalina, zapomnianym obliczu polskiego futuryzmu i nowych zjawiskach w literaturze popularnej. Kraków: Attyka. ISBN: 978-83-6564-445-9.

Kidd Colin. 1999. British Identities before Nationalism. Ethnicity and Nationhood in the Atlantic World, 1600-1800. Cambridge: Cambridge University Press. IBSN: 978-08-8208-092-5.

Kollontai Alexandra. 1977. Selected Writings of Alexandra Kollontai. Trans. Alix Holt. Westport: Norton. ISBN: 978-03-9300-974-3.

Krzychylkiewicz Agata. 2006. The Grotesque in the Works of Bruno Jasienski. Bern: Peter Lang. ISBN: 978-30-3911-217-3. 
Krzywicka Irena. 2008. Kontrola wspótczesności: Wybór międzywojennej publicystyki spotecznej i literackiej z lat 1924-1939. Ed. Agata Zawiszewska. Warszawa: Feminoteka. ISBN: 978-83-6220-664-3.

Kuligowski Waldemar. 2016. Chamska historia Polski. Tezy i antytezy. "Czas Kultury", no. 3. ISSN: 867-2148. Pp. 70-77.

Lee Stephen Richard. 1982. Trudne przymierze. Polska awangarda poetycka $w$ kregu idei lewicy (1918-1939). Warszawa: Państwowy Instytut Wydawniczy. ISBN: 978-83-0600-664-3.

Lipatow Aleksander W. 1992. Awangarda: pokusa poezji i utopia wtadzy. "Teksty Drugie", no. 1/2. ISSN: 0867-0633. Pp. 49-57.

Łuczewski Michat. 2012. Odwieczny naród. Polak i katolik w Żmiącej. Toruń: Wydawnictwo Naukowe Uniwersytetu Mikołaja Kopernika. ISBN: 978-83-2312-878-6.

Kysko Marcin. 2015. Udziat kobiet w życiu publicznym II Rzeczypospolitej Polskiej. "Miscellanea Historica-Juridica”, no. 1. ISSN: 1732-9132. Pp. 381-400.

Miller Jan Nepomucen. 1925. Kryzys egotyzmu. "Almanach Nowej Sztuki”, no. 1. Pp. 46-47.

Millet Kate. 1990. Sexual Politics. Urbana: University of Illinois Press. ISBN: 978-02-5206-889-8.

Miłosz Czesław. 1999. Wyprawa w Dwudziestolecie. Kraków: Wydawnictwo Literackie. ISBN: 978-83-0804-531-2.

Nietzsche Friedrich. 1989. On Truth and Lying in an Extra-Moral Sense. In: Friedrich Nietzsche on Rhetoric and Language. Ed. and trans. Sander L. Gilman, Carole Blair, David J. Parent. Oxford: Oxford University Press. ISBN: 978-01-9505-159-9. Pp. 246-257.

Pobłocki Kacper. 2016. How Poles Became White. In: Halka/Haiti. 1848'05"N 72²3'01 "W. Ed. Magdalena Moskalewicz. Warszawa: Zachęta. ISBN: 978-83-6471415-3. Pp. 107-119.

Pogonowska Ewa. 2002. Dzikie biesy. Wizja Rosji sowieckiej w antybolszewickiej poezji polskiej lat 1917-1932. Lublin: Wydawnictwo Uniwersytetu Marii Curie-Skłodowskiej. ISBN: 978-83-2271-909-1.

Ram Harsha. 2012. Futurist Geographies: Uneven Modernities and the Struggle for Aesthetic Autonomy: Paris, Italy, Russia, 1909-1914. In: The Oxford Handbook of Global Modernisms. Ed. Mark Wollaeger, Matt Eatough. Oxford: Oxford University Press. ISBN: 978-01-9932-470-5. Pp. 314-340.

Rancière Jacques. 1998. Disagreement Politics and Philosophy. Trans. Julie Rose. Minneapolis: University of Minnesota Press. ISBN: 0-8166-2844-0.

Rancière Jacques. 2009a. The Aesthetic Dimension: Aesthetics, Politics, Knowledge. "Critical Inquiry", no. 36. ISSN: 0093-1896. Pp. 1-19.

Rancière Jacques. 2009b. Na brzegach politycznego. Trans. Iwona Bojadżijewa, Jan Sowa. Kraków: Ha!art. ISBN: 978-83-6140-736-2. 
Rancière Jacques. 2015. Polityka literatury. Trans. Jerzy Franczak. In: Socjologia literatury. Antologia. Ed. Grzegorz Jankowicz Michał Tabaczyński. Kraków: Ha!art. ISBN: 978-83-6405-763-2. Pp. 350-374.

Rauszer Michał. 2018. Dwa ciata króla i naród polityczny. Ksztattowanie się tożsamości chtopskiej w kontekście procesów narodowotwórczych. "Spawy Narodowościowe", no. 50. ISSN: 2392-2427. Pp. 1-12.

Rawiński Marian. 1971. "Stowo o Jakubie Szeli" Brunona Jasieńskiego wobec folkloru. "Pamiętnik Literacki”, no. 62. ISSN: 0031-0514. Pp. 81-118.

Rose Edward. 1922. Bilans gospodarczy trzech lat niepodlegtości. Warszawa: Gebethner i Wolff.

Rybicka Elżbieta. 2000. Projektowanie miasta (o dyskursie urbanistycznym dwudziestolecia). "Teksty Drugie", no. 4. ISSN: 0867-0633. Pp. 57-72.

Said Edward. 1979. Orientalism. New York: Vintage Books. ISBN: 0-3947-4067-X.

Stern Anatol. 1923. Zwierzęta w klatce. O polskim futuryzmie. "Kurier Polski”, no. 19. P. 8.

Stern Anatol. 1969. Bruno Jasieński. Warszawa: Wiedza Powszechna.

Stern Anatol. 1985. Europa. In: Wiersze zebrane. Vol. 1. Ed. Andrzej K. Waśkiewicz. Kraków: Wydawnictwo Literackie. ISBN: 83-0800-942-5. Pp. 200-206.

Stern Anatol, Wat Aleksander. 1978. Prymitywiści do narodów świata i do Polski. In: Antologia polskiego futuryzmu i Nowej Sztuki. Ed. Zbigniew Jarosiński, Helena Zaworska. Wrocław: Ossolineum. Pp. 3-6.

Stępień Marian. 1985. Polska lewica literacka. Warszawa: PWN. ISBN: 978-830104-877-8.

Syrkus Szymon. 1926. Preliminarz architektury. "Praesens. Kwartalnik modernistów", no. 1. Pp. 6-16.

Theweleit Klaus. 1987. Male Fantasies. Vol. 1. Minneapolis: University of Minnesota Press. ISBN: 978-08-1661-449-3.

Theweleit Klaus. 1989. Male Fantasies. Vol. 2. Minneapolis: University of Minnesota Press. ISBN: 978-08-1661-451-6.

Trzynadlowski Jan. 1977. Futuryzm polski. In: Futuryzm i jego warianty w literaturze europejskiej. Ed. Józef Heinstein. Wrocław: Wydawnictwo Uniwersytetu Wrocławskiego. Pp. 97-112.

Wallerstein Immanuel. 2004. World-systems Analysis. An Introduction. DurhamLondon: Duke University Press. ISBN: 978-08-2233-442-2.

Wierzbiński Maciej. 1921. Gtupota czy zbrodnia. "Rzeczpospolita”, no. 341. P. 108.

Witos Wincenty. 1988. Dzieta wybrane. Moje wspomnienia. Warszawa: Ludowa Spółdzielnia Wydawnicza. ISBN: 978-83-2053-372-9. 
Wójtowicz Aleksander. 2019. Czarne i czerwone. Masy ludzkie w poezji polskiego futuryzmu. "Praktyka Teoretyczna", no. 3. ISSN: 2081-8130. Pp. 29-44.

Zaworska Helena. 1963. O Nowa Sztukę. Polskie programy artystyczne lat 1917-1922. Warszawa: PIW.

Żarnowski Janusz. 1973. Spoteczeństwo Drugiej Rzeczypospolitej 1918-1939. Warszawa: PWN.

Kasper Pfeifer

\title{
POLISH FUTURISM AND ITS PROJECT OF EMANCIPATION
}

\author{
(abstract)
}

The aim of this article is to present the forward-looking project of Polish Futurism, seen as a radical critical movement. It focuses on the concept of the "futurization of life", one of the main ideas postulated by the Polish Futurists, also referred to as the quasiaccelerationist modernization of the social reality of interwar Poland, which served as a response to the semi-peripheral status of the country. Taking recourse to Jacques Rancière and Immanuel Wallerstein, the article discusses the postulates of the Polish Futurists and the ways in which they wanted to achieve the following goals: to intervene in language in a revolutionary manner, to break free from the bourgeois culture, to democratize art, to emancipate women, to extend the notion of a nation, and to abolish the division of the world into the core and its periphery.

\section{SŁOWA KLUCZOWE}

futuryzm; studia nad utopią; estetyka i polityka; literatura polska; rewolucje; Jacques Rancière; Bruno Jasieński 